\title{
CONTINUITY OF WOMANIST ETHOS: INTERTEXTUALITY IN SELECT NOVELS OF ALICE WALKER
}

\begin{abstract}
This study uses the relational content analysis method and theories of intertextuality, intersectionality, and womanism to explore the continuity of womanist ethos in select novels of the African-American novelist Alice Walker. It attempts to explore Walker's use of womanism as an intertextual trope in The Third Life of Grange Copeland (1970), Meridian (1976), The Color Purple (1982), The Temple of My Familiar (1989) and Possessing the Secret of Joy (1992); Walker's portrayal of Celie-Shug as a perfect womanist couple in Color Purple and their reappearance in Temple as mother trees; foremothers as role models in Third Life and Temple; Walker's telling and retelling of Tashi's life-long suffering from female genital mutilation (FGM) in Color Purple, Temple, and Possessing - the subject of this paper.
\end{abstract}

Keywords: Alice Walker; intertextuality; intersectionality; womanism; role models; female genital mutilation; episodic memory.

Walker's novels have separately been explored from multiple perspectives, such as racism, sexism, an interlocking system of women's oppression, lesbianism, feminism, ecofeminism, socialist feminism, womanism, archetypal symbolism, sexuality, FGM, human rights violation, etc, till date. However, the attempts to explore appearance and reappearance of Celie-Shug; telling and retelling of Tashi's genital mutilation; and/or Walker's use of womanism as an intertextual trope in select novels are the point of departure of the study. The study is significant as it aims to locate Walker's use of an interlinking of past and present to foster a holistic approach to life, assert/establish an interlinked community identity, thereby creating a vision of wholeness in the society. Her select novels reveal an intertextual relation in that some iconic Walkerian

* Khulna University; Bangladesh. 
characters, such as Celie-Shug, Tashi, and several other womanist characters in her novels, reappear so as to nourish their succeeding generations with their womanist ideologies and to exhibit universality of women's bonding. Like mother trees, the duos transfer their resources/ideologies to the next generation and enhance an interlinked community identity. Thus, a reaffirmation of African Americans' connection to each other, a continued creation of a community identity, and/or an interconnected matrix of black women's solidarity across the ages and boundaries will be explored in the findings of the study.

\section{Theories of Intertextuality, Intersectionality, \& Womanism}

The study uses theory of intertextuality. Julia Kristeva coined the term and attempted to combine Saussurean and Bakhtinian theories of language and literature which produced the first articulation of intertextual theory in the late 1960s (Allen 1-2). Every text has its meaning in relation to other texts. This relationality can itself be figured in various ways. It involves a radical plurality of the sign, relation between signs and texts and cultural text, relation between a text and literary system, or the transformative relation between one text and another text. Intertextuality promotes a new vision of meaning, and thus of authorship and reading: a vision resistant to ingrained notions of originality, uniqueness, singularity, and autonomy (Allen 6). The concept of text is not a selfcontained structure, rather differential/historical. Texts are shaped not by an immanent time, but by the play of divergent temporalities (Frow 45).

The study also uses womanist theory and interchangeably uses 'womanist' and 'womanism' in the paper. The term, 'womanist', is coined by Walker in her 1983 book, In Search of Our Mothers' Garden: Womanist Prose. Bates puts, Walker returns to the historical past in order to comprehend the present (37). The diving into the past actually takes place in memory. Bates maintains that "womanist is a theory in the creative aesthetics of African American women and women of colour" (41). Walker's womanist loves other women sexually and/or nonsexually. She is committed to survival and wholeness of entire people (Walker, In Search xi). A womanist breaks class barriers and asserts solidarity with women irrespective of race, class, and sexuality. She asserts her personal career choices, sexual preferences, claims/establishes her space in the society, and builds up a community identity. Unlike Clenora Hudson-Weems' Africana womanism, Walker's womanist theory considers gender as an issue in women's struggles and rejects the male as an enemy. Donnelly maintains that Walker resists the 
term 'feminist' as she thinks that it ignores the particular problems of women of colour (66). She, however, prefers the term, 'womanist'. Like intersectional feminists, Walkerian womanists concurrently point out intersections or women's oppressions of all kinds, such as racism, sexism, classism, etc. bell hooks in her 1982 book, Ain't I a Woman: Black Women and Feminism, criticizes most of the feminists who assume that women of colour face only racial oppression. hooks criticizes the way those feminists think that the issue of race from sex and vice versa are separate. hooks and Walker believe that the issues are inextricably interwoven and are responsible for creating an unjust power relation in society. hooks argues that sexism operates both independently and simultaneously with racism to oppress black women. When black people are talked about, the focus tends to be on black men; and when women are talked about, the focus tends to be on white women (7). Thus, she points out an arbitrary exclusion of black women from history.

Walker uses womanism as a dominant intertextual trope in Third Life, Meridian, Color Purple, Temple, and Possessing. Walker, in In Search, Living by the Word, and in numerous interviews, "articulates her political and aesthetic vision as a 'womanist' committed 'to survival and wholeness of entire people, male and female,' beginning with 'my people' and 'black women,' extending to 'the multiplicity of oppression - and of struggle,' and ultimately to 'human life' and the polluted earth" (Braendlin 116). Walker uses womanism to interweave past and present, interlink individual and community identity, connect personal changes with that of political in the novels. By means of this trope, Walkerian womanists break class barriers and assert their solidarity with other women. They raise voices to define/redefine themselves. Walker's womanists, such as Margaret, Mem, and Ruth from three consecutive generations in Third Life, equate womanism with coping/healing strategy in the face of intersectional experiences. Margaret breaks an imposed gender performativity and racial/class barriers by engaging in an extra-marital relation with a white man and gives birth to a baby of mixed colour. This dauntless act is performative and instrumental in a sense that she becomes able to gather courage to affirm her individual choices/preferences. This tendency also finds better expression in Mem's, Margaret's daughter-in-law, assertion to lead her life according to her own will. Mem makes her own decision without her husband's (Brownfield) permission and continues her struggles to find her own home or space in the society. As Christian argues, Mem assaults Brownfield's definition of himself; he 
is also assaulted by Mem's redefinition of herself (61-62). Brownfield ends Mem's life using a gun; but he fails to halt her legacy. Butler claims, "Mem provides Ruth with a powerful role model, for she is a woman who maintains her human dignity in a dehumanizing environment" (94). Mem's daughter, Ruth, is a "sole survivor" (Walker 318) and is an ideal successor. Ruth carries her foremothers/role models' unfinished womanist tasks with the help of her grandfather, Grange, within a space of constraint. Walker says, "[T]o survive whole was what he wanted for Ruth" (Walker, Third Life 272). As such, an intergenerational transmission and practice of womanist way of life in the lives of three generations of women bespeak of a continuity of womanist ethos and a collective women identity. Bates states that wholeness can be accomplished by redirecting attention to the ancestors (50). Third Life's reconnection with ancestors of three generations - "a rich heritage of sister warriors" (Bates 50) - finds an intertextual connection with women characters in Temple, yet with a broader scale of five hundred millennia. Besides, an interconnectedness of several stories of intersectional oppression told by Lissie finds a similitude to Meridian. For instance, an emergence and later impact of Civil Rights Movement can only be realized upon looking back in time. In this regard, Bates is of the view that history of the South or African Americans' struggle uncovers an interconnectedness of the Movement with other movements in whatever time or place or space in history (80-1). An increasing awareness of social conflicts and changes gives rise to advents of other movements.

Third Life has an intertextual relatedness with Walker's next published novel, Meridian in that the later novel shows Meridian Hill's womanist thought and practice. An interlocking system of race and gender connects Meridian's personal experiences with larger socio-political upheavals. Stein says, Meridian's hope for a just society inheres not merely in political change, but in personal transformation (130). She struggles to redefine herself amid the Civil Rights Movement which could also reaffirm African Americans' connection to each other. With this realization, she participates in the movement; but her group becomes hostile to her when she refuses to kill for revolution. Besides, an act of aborting her child is crucial in that it suggests her refusal to internalize an imposed gendered identity. Meridian turns her back on Truman who betrays her for a white woman (Lynne) as well as betrays his own black community. She chooses education over motherhood as Truman proves to be unfaithful. Since she believes in freedom of her will and a continued effort to build a community 
identity, she boldly breaks the racial and gender expectations/specificities and creates women's space and possibilities. She avoids imposed motherhood and pursues "her goals of movement participation, organizing the community, teaching, and writing poetry in the rural South" (Bates 81). Meridian's womanist identity gives her a sense of latent potentiality, a sense of belonging to the black community, and a healing power to soothe her injured soul.

Bates argues that Walker explores the relevance of past events and their influence on future possibilities (83). In connection with Walker's interlinking of past and present, Meridian takes historical precedent to raise civil disobedience without violence in order to establish a collective black identity and civil rights for black people. As an institution, apart from Louvinie and Sojourner Truth, Mrs. Hill (Meridian's mother) energizes Meridian as follows: “Meridian thought of her mother as Black Motherhood personified, and that great institution she was..." (Walker, Meridian 96).

Meridian's bold act of asserting her individual choice to break up with Truman finds an intertextual clue to Celie's disapproval of her husband (Albert) and Nettie's strong disapproval to sexually satisfy Albert, her brother-in-law, in Color Purple. Celie ceases to follow orders of her husband who treats her just like a sex or domestic slave. Celie's step daughter-in-law (Sofia) and Albert's mistress (Shug) have been her role models. Celie after years of abuse learns from Sofia and Shug how to rebel against culturally imposed gender performativity. Jesmin contends that Celie internalizes Shug's spirit inside her to follow her ways which leads Celie to get social recognition" ("Socialist Feminist Reading" 51). Shug's spirit is truly womanist. She sexually/non-sexually loves Celie and Albert and also makes them follow her ways. Shug's role is significant in that she is Celie's mentor, mother-surrogate, and beloved at the same time. Celie's character is completely shaped by Shug's womanist spirit. It is Shug who takes the lead and establishes women's solidarity with other womanists, such as Sofia, Mary Agnes, and of course Celie in the novel. She encourages Celie to claim her own body, status in society, and to assert her sexual freedom. As a womanist, Shug teaches Celie to not separate herself from Albert. She teaches Celie that a strong, courageous, and a lesbian woman is able to live with a male partner with liberty, equality, and human dignity. As such, Shug remains Walker's spokesperson for upholding womanist vision. It resounds in Temple in which womanist spirit and performativeness are evident.

Lissie, like Meridian and Celie-Shug, is a thorough womanist who survives 
mutually-constitutive intersectional experiences and serves as an interlinking point to twin one with another and present with past.

Smith argues Lissie becomes 'a paradigm of redemptive intertextuality'. She is Walker's spirit made text, many times over, each successive text a 'repetition and revision' of past selves (75-76). Major women characters, such as Lissie, Fanny, and Carlotta, effectively use story-telling technique to narrate their past and present. Their struggle to quilt their past and present with a parallel precedence help them restore their past and weave future. Here, Lissie's memory/re-memory and/or role are instrumental in that she reincarnates throughout generations. Bates views Lissie as an ancient goddess, incarnated multiple times as a woman, man, lion, and a white male (111). She looks back on her rape and mutilation as a slave, witch hunting, and her murder. She narrates her lives through a detailed episodic memory and oral history. Her hippocampus, a major component of the brain of humans and vertebrates, acts like a router to link each of her past experiences/events and related memories, to store new memories, and to connect certain emotions to these memories. Hippocampus is "crucial for long-term episodic memory" (Bird and Burgess 182). Lissie's present experiences trigger her going back to past experiences of similar and different kind.

The connection between utterances and episodic memories is made through hippocampus. This is made possible by Walker's skilful interlinking of time (past and present), memory/re-memory, and history/revisiting history. Time, covering five hundred millennia, reflects "the intricacies of interconnected lives" (Bates 109) in Temple. Donnelly calls Lissie an "eternal mother ancestor" (117). Her rebirth reconnects other characters with their ancestors, just the same way Walker rediscovers ancient African goddesses (Isis and Medusa) to develop the novel's fundamental theme of quilting past and present for the purpose of attaining healing power as well as connectedness. As Bates maintains:

Lissie's memory is remarkable, revealing that she has lived in different incarnations since the beginning of time; she is even able to relate the origin of women's loss of dignity and integrity. This story sets into motion the myriad voices that explain the interconnectedness between the ancient order and contemporary times. (108)

Walker's epistolary narrative technique in Color Purple also helps narrating 
University of Bucharest Review $\propto$ Vol. X/2020, no. 1 (new series)

Re-writing, Re-imagining the Past (I)

Celie and Nettie's past and present. It helps them identify/discover themselves and their times. Their struggle to get rid of intersections of race and sex marks their developing selves. If they deny outcomes of intersections for which they/their people suffer, it would certainly cause subjective loss of some of the traumatic object relations of their past. An intertwining of their past and present helps them to realize their status and form their womanist identities. In Temple, characters' story-telling along with other narrative techniques, like diary, letter, painting, and music, serves as a creative release from the agonizing memory/history. Walker's use of letter writing as a dominant narrative technique in Color Purple finds an instrumental literary continuity in Temple. This technique/mode of expression serves as a matrix for creating new associations with past and communal connections among women in both the novels. It is essentially womanism at its core. The womanists do not deny their past; rather their past shapes and most importantly recreates them so as to continue their journeys towards wholeness. Walker in an interview with Claudia Dreifus in 1989 has said of Temple, "[w]hat I'm doing is literarily trying to reconnect us to our ancestors. All of us. I'm really trying to do that because I see that ancient past as the future, that the connection that was original is a connection" (qtd. in Braendlin 121).

Walker portrays Celie-Shug as a perfect womanist couple in Color Purple and their reappearance in Temple as mother trees. Celie-Shug's, from Color Purple, reappearance as grandmothers of Fanny in Temple, is crucial in that the couple effectively advocates womanism as a guiding principle to lead life. Like mother trees, they are closely connected to the lives of their succeeding generations of women in Temple. Acknowledging the presence of Celie ('Big Mama/Grandmama') and Shug ('Mama Shug') and their tremendous spiritual support to Fanny, Fanny admits that her childhood has been full of joy, enthusiasm, and "the cosiness of being loved" (Walker, Temple 154) by her grandmothers. She says, "That period of my life was a long bliss. Very little happened that I considered threatening to me...all my womanish ways were approved" (Walker, Temple 154). Her womanist grandmothers take good care of Fanny so that she does not experience anything threatening. They also approve her womanist way of leading life. This bond of two generations (grandmothers and granddaughter) resounds in the bond between Grange as grandfather and Ruth as his granddaughter in Third Life.

Intertextual relations between the texts are formed on the basis of 
womanism. Celie and Shug transfer their womanist philosophy to their next generations, thereby enhancing an interlinked community identity. Walker's purposeful reinclusion of the womanist couple, literary continuity of womanism as a central trope in her novels, and her emphasis on foremothers as role models mark her emphasis on womanism. Walker simultaneously uses past and present to weave the future. Walker carries the womanist legacy from her literary foremother, Zora Neale Hurston. Hurston's protagonist, Janie in Their Eyes Were Watching God (1937), boldly breaks silence, smashes imposed barriers, gains a self-defined voice, and secures her freedom. Hurston's Janie as a womanist has been obsessed with her own fantasy, freedom, and identity. Referring to Janie's journey to assert herself, Saunders says that womanism functions as a common trope in Their Eyes and Color Purple (1-11). Walker, however, gives a new dimension to the trope or womanist characterization in her novels. Walker has presumably modelled her characters in the Hurstonian womanist fashion, yet with a revising and/or an innovation of her own. The idea is that Walkerian womanists are concerned with wholeness of their selves and society and community identity at the same time.

Walker's womanism reflects on "black women's connection between the self and the community" (Harris 43). In this connection, Celie, Nettie, Shug, Sofia, and Mary Agnes play significant roles. They perceive deepest sensitivities towards the needs of other women associated with them and women around them. They feel that they are not free from the devastating impact of intersections of race and sex until other women are not free. This makes Celie, Shug, and Mary Agnes help Sofia to free her from prison. Sofia's outright rejection to be the maid of Mrs. Mayor (a white) in Color Purple and subsequent fight land her in an unjust imprisonment for twelve years. The facts that she is a woman and is a black are the causes behind this unwarranted punishment. She courageously survives intersectional oppression in the prison and Mayor's house and becomes able to take good care of Mayor's daughter, Eleanor Jane nevertheless. "Jane is against her father's racist and sexist attitudes and develops a sort of sisterly/motherly bonds with Sofia. In a compensatory manner, Jane emotionally supports Sofia and the latter's daughter, Henrietta" (Jesmin, "Socialist Feminist Reading", 56). Meridian fits the criteria of womanist as she herself exercises liberty and works as an activist to devote her life to freedom causes, thus becomes "an agent of [social] change" (Bates 73). Keeping Still and Worton's notions - a text does not function as a self-sufficient whole or a closed system (1) - in mind, Meridian's political 
awakening from a typical mother figure finds an intertextual relation with Celie in Color Purple. Celie awakens from her domestic/sexual slavery and begins a capitalist venture of a Folkspants business in Memphis. In a letter to Nettie, Celie says about her great efforts of making a perfect pair of pants with joy as follows:

I sit in the dining room making pants after pants. I got pants now hi every color and size under the sun...I change the cloth, I change the print, I change the waist, I change the pocket. I change the hem, I change the fullness of the leg. I make so many pants Shug tease me...How much money you think you need this week? Then finally one day I made the perfect pair of pants. (Walker, Color Purple 191)

Celie takes an active part in commodity production and employment of labourers. Jesmin's socialist feminist reading of Color Purple reveals that Celie, including Nettie, Shug, Sofia, and Mary Agnes, contribute to the society and economy by means of their role in reproduction, production, and consumption (45). As such, they, like Meridian, are agents of social changes. Temple raises interlocking issues (such as African slave trade and oppression on women of color) of race and sex on personal, communal, and global levels through characterization of Lissie with her remarkable episodic memories. When Suwelo asks Lissie about 'peace', she says, "In lifetime after lifetime I have known oppression" (Walker, Temple 82). Knowing past is painful, nevertheless she teaches Suwelo to know and accept past to make his way towards future. As Braendlin argues, Lissie, the reincarnated storyteller, is already self-aware and socially conscious, burning with a righteous anger that is more social than personal (120).

An interconnected matrix of race and sex is responsible for the oppression (in greater or lesser degree) on almost all the women characters in Walker's select novels and murder of women and children. Margaret dies by suicide; her mulatto child is killed; Mem is killed in Third Life. Meridian's fetus is aborted; Lynne's daughter (Camara) is raped and murdered; Celie's biological father is killed by some white people. Tashi's sister (Dura) bleeds to death, due to a botched FGM, including several others at Olinka village and by implication thousand others in various parts of the world. In Possessing, female genital mutilator (tsunga as M'Lissa) is murdered as a consequence of Tashi's attempt to eradicate an imposed inhuman practice of FGM. The mutilated (Tashi) undergoes 
an intersectional oppression throughout her life. Performing FGM on her and her execution in the novel bespeak of an intersectional oppression. This is because she is black and a female; she is treated as neither African nor American during her court trial for her murder of the national monument like M'Lissa. "Interrelatedness of power relations makes Tashi a sexual-political subject in her own culture. She experiences the crises of racial otherness in Africa as well as America" (Jesmin, "Cultural and Political Paradigms" 46). Worth pondering is just the aforementioned black women's struggle for surviving and living whole despite unjust socio-political power relations. Lissie identifies herself with all of them; she experiences of what others undergo. Thus, Walker's womanist ethos finds continuity.

Walker's tellling of Tashi's FGM in Color Purple, reinclusion/retelling of Tashi in her next novel, Temple, her rewriting of Tashi's "harrowing tale of her mutilated genital and tortured soul" (Jesmin, "Cultural and Political Paradigms" 43) in Possessing, her portrayal of Tashi as a fighter and survivor of FGM explicitly manifests intertextual connections among these texts. As Jesmin claims, Tashi is the representative of millions of infibulated women who undergo the millennia-old horrific practice. Tashi kills the tsunga (mutilator), admits to her sister-in-law (Olivia) that she has not killed her mutilator in the name of the suffering she has caused to her. In fact, she dearly cherishes her own freedom from her agonizing life and also intends to free other little girls from the ritualized violence ("Cultural and Political Paradigms" 39-45). Tashi also frees the mutilator who herself admits that she painfully performs FGM on adolescent Olinkan girls as an obligatory community task. It makes Tashi a true womanist who possesses the power of resistance and makes both the mutilator and the mutilated free from performing/undergoing FGM. The racist-sexist Olinkan government executes Tashi for her violation of socio-cultural and political norms.

It clearly reveals the proliferation of an intersectional power dynamics. Tashi says, "it was only the murder of the tsunga...by one of those whom she has circumcised that proves her (the circumciser's) value to her tribe" (Walker, Possessing 165). Both the mutilator (M'Lissa) and mutilated (Tashi) are freed and honoured only after their murder/execution. Whether the mutilator defends the culture or the mutilated transgresses the culture, both of them in both the cases would be under a culturally-shaped sharp knife much like the tsunga's knife from which no female will be exempted. Thus, they are compelled to sacrifice their lives. Worth mentioning is women's continuity of the struggle to survive whole. 
Foremothers' struggle and sacrifice conjoining with that of their successors bring about social changes. Tashi is Adam's wife, and thus she is Celie's daughter-inlaw in the select novels. Both of them directly/indirectly influence Tashi to lead her life like a womanist. Bates contends that Possessing is written from a womanist perspective as it shows "how one woman musters the strength to stand up and react in a situation..." (115). Tashi's execution resonates in the murder of Mem. When they cease to adhere to the social norms, they are punished to terrorize other women of their kind in their respective societies. Such an ill motive to deter the women from undoing gender performativity falls flat. This is because Mem's succeeding generations, such as Ruth, Meridian, Celie, Nettie, Shug, Sofia, Mary Agnes, Lissie, Tashi, and so on, gradually but firmly smash the barriers that forbid transgressing a race/sex specific domain.

\section{Conclusion}

Bates maintains that the term womanist refers to women of colour who embrace universality rather than separatism. Womanists are survivors who form bonds by empowering themselves and other women. An ideal womanist develops a liberated spirit and always emerges as a whole human being (99-100). In an attempt to search for her literary foremothers, such as Phillis Wheatley and Hurston, and so on, and/or reconnect with past, Walker writes In Search, thereby advancing her womanist theory. This is more than a theory, as it shows a totality of life to accept/define/claim the mind and body of women of colour. A womanist way of life guides the women characters, such as Margaret, Mem, Ruth, Meridian, Celie, Nettie, Shug, Sofia, Mary Agnes, Lissie, and Tashi, to struggle for accepting their selves, getting their basic rights, asserting their individual choices and sexual preferences, and for creating community identity. Walker's recurring use of womanist ideal in the select novels reflects an intertextual literary continuity. The study finds Walker's use of womanism as a dominant intertextual trope in her select novels. The womanists open up possibilities out of impossibilities. Walker's portrayal (lesser or greater degree) of Tashi in three consecutive novels itself along with its cultural and political implications manifests intertextual links among the novels. The link is established on the basis of Walker's womanist vision in that Tashi takes decision for herself and others too. She frees herself from an agonizing life and murders the mutilator to eradicate FGM. Walker's womanist vision manifests her earnest sense of community building and accordingly carries cultural and practical implications. 


\section{Works Cited}

Allen, Graham. Intertextuality. London: Routledge, 2000.

Bates, Gerri. Alice Walker: A Critical Companion. Westport, Conn.: Greenwood Press, 2005: 108-11.

https://archive.org/details/alicewalkercriti0000bate_e7j1/page/108/mode/2up

Bird, Chris M., and Neil Burgess. "The Hippocampus and Memory: Insights from Spatial Processing." Nature Reviews Neuroscience 9 (2008): 182-94. https://doi.org/10.1038/nrn2335

Braendlin, Bonnie. "Alice Walker's The Temple of My Familiar as a Pastiche." Bloom's Modern Critical Views: Alice Walker. Ed. Harold Bloom. New York: Chelsea House, 2007: 116-21.

Butler, Robert James. "Alice Walker's Vision of the South in The Third Life of Grange Copeland." Bloom's Modern Critical Views: Alice Walker. Ed. Harold Bloom. New York: Chelsea House, 2007: 94.

Christian, Barbara. "Novels for Everyday Use." Alice Walker: Critical Perspectives Past and Present. Eds. Henry Louis Gates and Anthony Appiah. New York: Amistad, 1993: 61-2.

https://archive.org/details/alicewalker00alic/page/62/mode/2up

Donnelly, Mary. Alice Walker: The Color Purple and Other Works. New York: Marshall Cavendish Benchmark, 2010: 66-117.

Frow, John. "Intertextuality and Ontology." Intertextuality: Theories and Practices. Eds. Michael Worton and Judith Still. Manchester and New York: Manchester UP, 1990: 45.

Harris, Melanie L. Gifts of Virtue, Alice Walker, and Womanist Ethics. New York: Palgrave Macmillan, 2010: 43.

hooks, bell. Ain't I a Woman: Black Women and Feminism. London: Pluto Press, 1982: 7.

Jesmin, U. H. Ruhina. “A Socialist Feminist Reading of Alice Walker's The Color Purple." Harvest 33 (2019): 45-51. Print.

--.."Cultural and Political Paradigms of FGM: An Intersection of Race and Sex in Alice Walker's Possessing the Secret of Joy." Meridian Critic 33 (2019): 3747. http://meridiancritic.usv.ro//index.php?page=2019-2-ro

Phillips, Layli. The Womanist Reader. New York: Routledge, 2006: xxv-xxvi.

Saunders, James Robert. "Womanism as the Key to Understanding Zora Neale Hurston's Their Eyes Were Watching God and Alice Walker's The Color 
Purple." Hollins Critic 25. 4 (1988):1-11.

Smith, Felipe. "Alice Walker's Redemptive Art." Bloom's Modern Critical Views: Alice Walker. Ed. Harold Bloom. New York: Chelsea House, 2007: 75-6.

Stein, Karen F. "Meridian: Alice Walker's Critique of Revolution." Black American Literature Forum 20 (1986): 130.

Still, Judith, and Michael Worton. "Introduction." Intertextuality: Theories and Practices. Eds. Michael Worton and Judith Still. Manchester and New York: Manchester UP, 1990:1.

Walker, Alice. In Search of Our Mothers' Gardens: Womanist Prose. San Diego: Harcourt Brace Jovanovich, 1983: xi-xii; 250.

https://archive.org/details/insearchofourmot00walk/page/288 Accessed 3 Mar. 2020.

---. The Third Life of Grange Copeland. London: Phoenix, 2005. Print.

---. Meridian. New York: Harcourt Brace Jovanovich. 2004. Print.

---. The Color Purple. London: Phoenix, 2004. Print.

---. The Temple of My Familiar. Boston: Mariner Books, 2010.

https://archive.org/details/isbn_9780547480008/page/172/mode/2up

---. Possessing the Secret of Joy. New York: Open Road, 1992. 